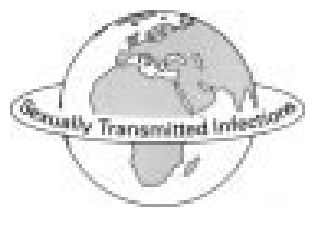

\title{
Global views
}

\section{HSV-2 specific seroprevalence among various populations in Rome, Italy}

\section{Demographic data}

We conducted a cross sectional seroprevalence study on anonymous banked blood samples taken from adults for various reasons, between January and September 1998 at "La Sapienza" University Hospital, Rome, Italy. Blood samples were available for the following four groups of individuals: regions, undergoing routine medical examination for enrolment in the military service

(b) people attending an outpatient facility for either vaccination against viral hepatitis $\mathrm{B}$ or post-exposure prophylaxis

(c) blood donors

(d) pregnant women undergoing routine serological controls.

\section{Methods}

TEST USED

All samples were tested with a commercially available kit approved by the US Food and Drug Administration: the herpes simplex virus (HSV) type 2 specific gG ELISA test manufactured by Meridian Diagnostics Inc (Cincinnati, OH, USA). The sensitivity and specificity of the test are $98 \%$ and $97 \%$, respectively. ${ }^{1}$

STATISTICS

To test the difference between prevalence rates, we calculated $\chi^{2}$ and $\chi^{2}$ for linear trends and $95 \%$ confidence intervals.

\section{Results}

The study population consisted of 673 individuals. Table 1 presents the HSV-2 seroprevalence by sex, age, and group studied.

Seroprevalence was $4.9 \%$ (95\% CI: $3.1-$

7.3) among males and $6.7 \%(95 \% \mathrm{CI}$ : 3.8-10.8) among females, with no statistically significant difference between the two. (a) military recruits, from various Italian

We did not observe an increase in seroprevalence with age. No significant differences were observed among age groups in either males or females.

\section{Discussion}

Individuals included in this study are at low risk for HSV-2 infection and therefore are probably representative of the general population, although not enough information was available on behaviour to substantiate this statement.

The observed seroprevalence of $5.5 \%$ is similar to the $3.6 \%$ found in Spain among males and females from the general population, ${ }^{2}$ and four times lower than the $21.9 \%$ found in the United States among adults from the general population. ${ }^{3}$

The seroprevalence observed among military recruits is comparable with that reported by other studies conducted among individuals of a similar age, yet it is much higher than the $0.086 \%$ seroprevalence found in a previous Italian study on military recruits, based on blood samples drawn in 1981. ${ }^{4}$ However, these two studies used different HSV-2 antibody tests, and we cannot exclude a lower sensitivity of the older test.

With regard to blood donors, the seroprevalence found in our study is similar to that among blood donors in the United Kingdom. ${ }^{5}$

Among pregnant women, the $7.6 \%$ seroprevalence observed in our study is consistent with the $8.4 \%$ seroprevalence found in northern Italy in a similar setting, ${ }^{6}$ yet it is lower than that reported among pregnant women in other countries, ${ }^{7}$ although the wide confidence interval should be taken into consideration.

In agreement with the study conducted in Spain, ${ }^{2}$ we found no significant sex difference in seroprevalence and no increase in seroprevalence with age.

If our data are indeed representative of the general population, then they suggest that the

Table 1 HSV-2 seroprevalence by sex, age, and group studied

\begin{tabular}{|c|c|c|c|}
\hline & No of individuals & No of $H S V-2$ positive & $\%$ HSV-2 positive $(95 \% \mathrm{CI})$ \\
\hline Total & 673 & 37 & $5.5(3.9-7.5)$ \\
\hline \multicolumn{4}{|l|}{ Sex } \\
\hline Males (\%) & 448 & 22 & $4.9(3.1-7.3)$ \\
\hline Females (\%) & 225 & 15 & $6.7(3.8-10.8)$ \\
\hline \multicolumn{4}{|l|}{ Age (years) } \\
\hline $1-19$ & 168 & 6 & $3.6(1.3-7.6)$ \\
\hline $20-29$ & 152 & 12 & $7.9(4.1-13.4)$ \\
\hline $30-39$ & 171 & 7 & $4.1(1.7-8.3)$ \\
\hline $40-49$ & 98 & 6 & $6.1(2.3-12.8)$ \\
\hline $50-99$ & 84 & 6 & $7.1(2.7-14.9)$ \\
\hline \multicolumn{4}{|l|}{ Groups studied } \\
\hline Military recruits & 156 & 6 & $3.8(1.4-8.2)$ \\
\hline Outpatients & 272 & 15 & $5.5(3.0-8.7)$ \\
\hline Blood donors & 179 & 11 & $6.1(3.1-10.7)$ \\
\hline Pregnant women & 66 & 5 & $7.6(2.5-16.8)$ \\
\hline
\end{tabular}

seroprevalence of HSV-2 infection in Italy is lower than that reported in other industrialised countries, though the comparison between our data on military recruits and that from previous studies suggests that seroprevalence may have increased in Italy over the past 20 years.

The authors wish to thank GlaxoWellcome and Meridian Diagnostics for having made this study possible, and Mark Kanieff for linguistic revision of the manuscript.

B SULIGOI

Reparto AIDS e MST, Istituto Superiore di Sanità, Rome, Italy

M CUSAN

Istituto di Microbiologia, University of Padua, Padua, Italy

\section{P SANTOPADRE \\ Clinica Malattie Infettive, "La Sapienza" \\ University, Rome, Italy}

G PALÙ

Istituto di Microbiologia, University of Padua, Padua, Italy

S CATANIA

Clinica Malattie Infettive, "La Sapienza" University, Rome, Italy

G GIRELLI

Dipartimento di biotecnologie cellulari ed ematologia, "La Sapienza" University, Rome, Italy

Clinica Dermatologica, "La Sapienza" S PALA

University, Rome, Italy

V VULLO

Clinica Malattie Infettive, "La Sapienza" University, Rome, Italy

THE ITALIAN HERPES

MANAGEMENT FORUM*

Correspondence to: Barbara Suligoi, National AIDS and STD Unit, Istituto Superiore di Sanità, V le Regina Elena 299, 00161 Rome, Italy suligoi@iss.it

Contributors: BS analysed the data and wrote the manuscript; MC conducted laboratory analyses and data input; PS collected sera and demographic information; GP conducted laboratory analyses, coordinated laboratory activities, and revised the manuscript; CS provided sera from pregnant women and from the service for prophylaxis against hepatitis B; GG provided sera from blood donors; PS provided sera from military recruits; VV collected sera, coordinated the various sources of sera samples and revised the manuscript.

*The Inlian Herpes Mana mement Forum (consistThe Italian Herpes Management Forum (consisting of F Boselli, R Caputo, M Cusini, S Delia, G Gentile, P Martino, G Palu, B Suligoi, A Volpi, V and were involved in discussion of the results.

1 Ashley RL, Wu L, Pickering JW, et al. Premarket evaluation of a commercial glycoprotein G evaluation of a commercial glycoprotein $\mathrm{G}$
based enzyme immunoassay for herpes simplex based enzyme immunoassay for herpes simplex
virus type specific antibodies. $\mathcal{F}$ Clin Microbiol virus type specific
1998;36:294-5. 
2 Garcìa-Corbeira P, Dal-Rè R, Aguilar L, et al. Is exual transmission an important pattern fo herpes simplex type 2 virus seroconversion in the Spanish general population? F Med Viro 1999:59:194-7.

3 Fleming DT, McQuillan GM, Johnson RE, et al. Herpes simplex virus type 2 in the United States, 1976 to 1994 . N Engl F Med 1997;337 1105-11.
4 Pasquini P, Mele A, Franco E, et al. Prevalence of herpes simplex virus type 2 antibodies in selected population groups in Italy. Eur F Clin Microbiol Infect Dis 1988;7

5 Cowan FM, Johnson AM, Ashley R, et al. Relationship between antibodies to herpes simplex virus (HSV) and symptoms of HSV infection. F Infect Dis 1996;174:470-5.
6 Nahmias AJ, Lee FK, Beckman-Nahmias S. Sero-epidemiological and sociological patterns of herpes simplex virus infection in the world. Scand F Infect Dis 1990;69Suppl:19-36.

7 Arvaja M, Lethinen M, Koskela P, et al. Serological evaluation of herpes simplex virus type 1 and type 2 infections in pregnancy. Sex Transm Inf 1999;75:168-71.

\section{Syphilis and gonorrhoea in the Baltic countries}

\section{Introduction}

Syphilis has often been a problem of great concern in many countries and not only because if untreated the disease may affect any organ, but it can also be inherited-that is, children are born with congenital syphilis. ${ }^{1-6}$ After the second world war the highest indices in Latvia were recorded in 1973 (82.6 cases per 100000 people). With strict preventive measures the situation from 1980 to 1990 was comparatively good- $-5-10$ cases per 100000 inhabitants but since 1993 a dramatic increase in the incidence of syphilis has been noted again.

\section{Methods}

Syphilis was diagnosed by finding Treponema pallidum or by serological and immunofluorescence reactions (RPR, VDRL, TPHA, IFR abs IgM, IFA), gonorrhoea by finding gonococci and diagnosing by Gen-Probe Pace 2 and polymerase chain reaction.

\section{Results}

As seen in table 1, 1996 had the highest syphilis morbidity level over the previous 10 years; in Latvia there were 3124 cases and in Lithuania 3761, but in Estonia the highest level was in 1998, 1101.

Most alarming is the fact that the incidence of syphilis in Latvia is increasing among young people. In 1996, there were 10 cases in those aged 13-14 years and 184 cases in the age group 15-17 years; seven children acquired the disease from parents; and 25 cases were congenital. In 1998 the figure were five, 119; and seven; and 15, respectively.
The highest morbidity level of gonorrhoea over the past decade was in 1993 with 4223 cases in Latvia, 5626 cases in Lithuania, and 3535 in Estonia, and it is currently still high.

\section{Discussion}

In eastern Europe the incidence of syphilis in 1996 was the following: in Russia 263 cases, Kazakhstan 231, Moldavia 200, Belorus 210, Latvia 125, Estonia 66, Lithuania 101, and morbidity was dramatically increasing. ${ }^{4}$

In the United States in the early 1990s this was connected with the high level of drug addiction-"crack" cocaine use. ${ }^{1}$ This is partly the situation in Latvia, as well as in the other eastern European countries where the prostitution level is also very high.

Fluctuations in syphilis morbidity are parallel to changes in the political situation, increased migration of people, expanded import, and dissemination of pornographic information in the country. Since 1993, the rise in syphilis morbidity has been due to prostitution, publicised but medically uncontrolled, and to the rapid rise in the level of unemployment, alcohol abuse, drug addiction Advertising of prostitution is spreading. In Latvia more that 200 clubs offering services by prostitutes have sprung up although prostitution has not been legalised. ${ }^{5}$

Pornographic and sex literature are brought into Latvia and are widely available, lowering the morals and ethics of the population, particularly of teenagers. The same situation also exists in the neighbouring countries. ${ }^{45}$

\section{Conclusions}

In the years 1993-8 the number of cases of syphilis and gonorrhoea in Latvia, Lithuania, and Estonia was very high. A special national strategy programme to prevent further increase of syphilis, gonorrhoea, and other STDs should be developed.

A RUBINS S RUBINS I JAKABSONE

Chair of Dermatovenereology, Medical Academy of Latvia, Riga

Correspondence to: Professor Andris Y Rubins, Department of Dermatovenereology, Medical Academy of Latvia, Kr Valdemara Street 76-75, Riga, Latvia, LV-1013

arubins@apollo.lv

1 Buntin DM, Rosen T, Lesher JL Jr, et al. Sexually transmitted diseases: bacterial infections. Committee on Sexually Transmitted Diseases of the American Academy of Dermatology. F Am Acad Dermatol 1991;25:287-99.

2 Rubins S, Janiger CK, Schwartz RA. Congenital and acquired early childhood syphilis. Cutis 1995;56:132-6.

3 Edwards S, Carne C. Oral sex and the transmission of non-viral STIs. F Sex Transm Inf 1998;78:95-100

4 Renton AM, Borisenko KK, Meheus A, et al. Epidemic of syphilis in the newly independent states of the former Soviet Union (Editorial). Sex Transm Inf 1998;74:165-6.

5 Rubins A, Gutmane R, Rubins S, et al. Epidemiology of syphilis in Latvia. Acta Dermatol 1999;8:59-62.

6 Sanchez J, Gotuzzo E, Escamilla J, et al. Sexually transmitted infections in female sex workers: reduced by condom use but not by a limited periodic examination program. Sex Transm Dis 1998;25:82-9.

Table 1 Overview of syphilis and gonorrhoea found in Latvia, Lithuania, and Estonia 1991-8

\begin{tabular}{|c|c|c|c|c|c|c|c|c|c|c|c|c|c|c|c|c|}
\hline \multirow{2}{*}{$\begin{array}{l}\text { Country/ } \\
\text { cases of } \\
\text { infections }\end{array}$} & \multicolumn{2}{|l|}{1991} & \multicolumn{2}{|l|}{1992} & \multicolumn{2}{|l|}{1993} & \multicolumn{2}{|l|}{1994} & \multicolumn{2}{|l|}{1995} & \multicolumn{2}{|l|}{1996} & \multicolumn{2}{|l|}{1997} & \multicolumn{2}{|l|}{1998} \\
\hline & Total & $\begin{array}{l}\text { Per } \\
100000\end{array}$ & Total & $\begin{array}{l}\text { Per } \\
100000\end{array}$ & Total & $\begin{array}{l}\text { Per } \\
100000\end{array}$ & Total & $\begin{array}{l}\text { Per } \\
100000\end{array}$ & Total & $\begin{array}{l}\text { Per } \\
100000\end{array}$ & Total & $\begin{array}{l}\text { Per } \\
100000\end{array}$ & Total & $\begin{array}{l}\text { Per } \\
100000\end{array}$ & Total & $\begin{array}{l}\mathrm{Per} \\
100000\end{array}$ \\
\hline \multicolumn{17}{|c|}{ Latvia, 2.6 million population } \\
\hline Syphilis & $216^{\circ}$ & 8.1 & 273 & 10.3 & 830 & 31.8 & 1521 & 59.3 & 2357 & 91.9 & 3124 & 124.9 & 3008 & 121.3 & 2597 & 106 \\
\hline Gonorrhoea & 2466 & 92.4 & 3309 & 125.5 & 4223 & 162.0 & 3774 & 147.1 & 2853 & 111.2 & 2099 & 83.9 & 1690 & 88.1 & 1237 & 50.3 \\
\hline \multicolumn{17}{|c|}{ Lithuania, 3.7 million population } \\
\hline Syphilis & 180 & 4.86 & 286 & 7.72 & 694 & 18.72 & 2142 & 57.78 & 3379 & 91.15 & 3761 & 101.5 & 3146 & 84.86 & 2326 & 62.75 \\
\hline Gonorrhoea & 3071 & 82.8 & 4035 & 108.8 & 5626 & 151.7 & 5501 & 148.3 & 4057 & 109.4 & 2976 & 80.3 & 2021 & 54.5 & 1417 & 38.2 \\
\hline \multicolumn{17}{|c|}{ Estonia, 1.5 million population } \\
\hline Syphilis & 116 & 7.4 & 176 & 11.4 & 342 & 22.5 & 852 & 56.5 & 1034 & 70.4 & 972 & 66.2 & 1099 & 74.8 & 1101 & 76 \\
\hline Gonorrhoea & 2299 & 146.8 & 2790 & 180.7 & 3535 & 233.1 & 3099 & 205 & 2882 & 196.2 & 2437 & 169 & 1969 & 134 & 1477 & 101.9 \\
\hline
\end{tabular}

